\title{
The amphipod Corophium multisetosum (Corophiidae) in Ria de Aveiro (NW Portugal). II. Abundance, biomass and production
}

Received: 8 October 1999 / Accepted: 22 June 2000

\begin{abstract}
The abundance and biomass of Corophium multisetosum Stock, 1952 were determined from benthic corer samples collected monthly over $1 \mathrm{yr}$ in the upper reaches of Canal de Mira (Ria de Aveiro, Portugal). Both density and biomass over the sampling period were negatively correlated with water temperature and positively correlated with chlorophyll $a$ concentration in the sediment. C. multisetosum density was significantly negatively correlated with plant biomass and positively correlated with salinity. The nature of the sediment, favourable environmental conditions, high availability of food and low interspecific competition allowed the population to reach a maximal density of $200 \times 10^{3}$ individuals $\mathrm{m}^{-2}$ and a maximal biomass (ash-free dry wt, AFDW) of $62 \mathrm{~g}_{\text {AFDW }} \mathrm{m}^{-2}$. The population was highly productive, especially during the autumn/winter period. Production, estimated by two different methods (Hynes method: $251 \mathrm{~g}_{\mathrm{AFDW}} \mathrm{m}^{-2} \mathrm{yr}^{-1}$; Morin-Bourassa method: $308 \mathrm{~g}_{\mathrm{DW}} \mathrm{m}^{-2} \mathrm{yr}^{-1}$ ), was much higher than the values reported for other Corophium species. The annual P: $\overline{\mathrm{B}}$ ratio (10) was high, but similar to values reported for Swedish populations of $C$. volutator and lower than the values estimated from Mediterranean populations of C. insidiosum.
\end{abstract}

Communicated by S. A. Poulet, Roscoff

M. R. Cunha $(\bowtie) \cdot$ M. H. Moreira

Departamento de Biologia,

Universidade de Aveiro,

P-3810-193 Aveiro, Portugal

Fax: 00351234 426-408

e-mail:mcunha@bio.ua.pt

J. C. Sorbe

Laboratoire d'Océanographie Biologique,

UMR 5805 (CNRS-UB1),

2 rue du Professeur Jolyet,

F-33120 Arcachon, France

\section{Introduction}

Corophium Latreille, 1806 is a cosmopolitan genus in temperate and tropical waters, and is represented by 58 species, mostly shallow marine, and often found in estuaries, harbours and in European and Ponto Caspian rivers (Barnard and Karaman 1991). Corophium species are burrow- or tube-dwellers, feeding preferentially on detritus and epipelic microalgae, and can establish populations of extremely high densities in intertidal and subtidal areas. These amphipods are considered a key food source in mudflats used as foraging areas by migrating shorebirds, and are also an important part of the diet of fishes in sheltered coastal habitats that act as nursery and feeding grounds (Segestråle 1959; Goss-Custard 1977; Peer et al. 1986; Wilson 1989; Matthews et al. 1992).

In Europe, the most widespread and well studied species are Corophium volutator, $C$. arenarium and C. insidiosum. C. multisetosum was described by Stock (1952) from Dutch brackish waters and, since then, it as been reported from European brackish waters of the Baltic Sea and Atlantic coast (Janta 1995). In Portugal it is known from the Ria de Aveiro, the Mondego and Sado estuaries, and also from Ria Formosa, the southern limit of its distribution (Marques and Bellan-Santini 1985, 1986, 1990; Queiroga 1990; Cunha and Moreira 1995). This species preferentially inhabits low-salinity waters ( 0 to $20 \mathrm{psu})$ and sandy sediments (250 to $1000 \mu \mathrm{m})$, where it establishes populations reaching 200000 individuals $\mathrm{m}^{-2}$ (Baltic Sea: Janta 1995; Ria de Aveiro: Cunha and Moreira 1995). This amphipod is often found coexisting with the gastropod Potamopyrgus jenkinsi and the amphipod Gammarus chevreuxi. C. multisetosum is an abundant species in Ria de Aveiro, and its distribution in one of the main channels (Canal de Mira) was reported by Queiroga (1990). The species is also known from the other channels of the Ria, especially in shallow low-salinity areas. In higher-salinity areas it occurs mainly on intertidal sandy sediments near mean high water level (Cunha unpublished data). 
In this study, the fluctuations in density and biomass of Corophium multisetosum over $1 \mathrm{yr}$ period are discussed in relation to the temporal variation of some environmental factors. Its production in a shallow area at the upper reaches of Canal de Mira is estimated and compared to values for other Corophium populations.

\section{Material and methods}

\section{Study area}

The area investigated (Areão) in the Ria de Aveiro is located in the upper reaches of Canal de Mira (Fig. 1). The morphodynamics, circulation patterns and environmental gradients in Canal de Mira have been described by several authors (Teles et al. 1990; Moreira et al. 1993; Corrochano et al. 1997).

In Areão, the channel is narrow and shallow (average depth $<0.5 \mathrm{~m}$ at low water), with small intertidal areas (0 to $1 \mathrm{~m}$ ) and extensive macrophyte meadows (mainly Potamogeton spp. and Myriophyllum spp.) that almost completely cover the channel bed.

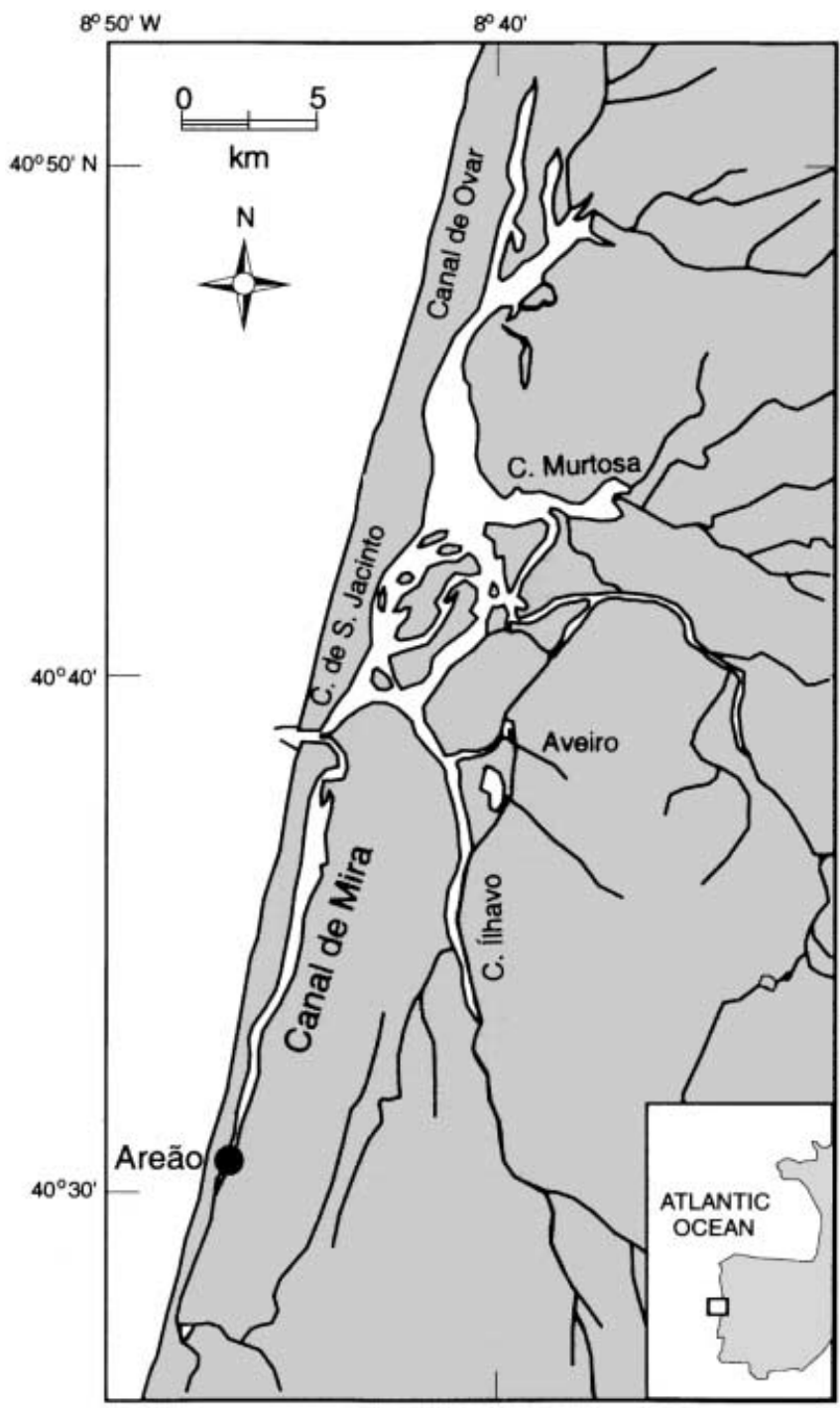

Fig. 1 Map of Ria de Aveiro and location of study area
The maximal tidal range is about $1 \mathrm{~m}$ at spring tides. During the sampling period, the salinity ranged from 0 to an extreme of 15 , but usually varied between 1 and 3 . Water temperature ranged from $8{ }^{\circ} \mathrm{C}$ (early morning during winter) to $25^{\circ} \mathrm{C}$ (afternoon during summer). Sediment type varied from medium sand $(\approx 75 \%$ of particles in the 250 to $500 \mu \mathrm{m}$ range) in the central channel to muddy sand in the banks. Fine particles $(<63 \mu \mathrm{m})$ represented $<7 \%$ of the sediment dry weight, and the average organic content was $3.5 \%$. [For further details on sampling and laboratory procedures see study of Cunha and Moreira (1995), who also provide complete description of the macrobenthic community structure and temporal (tidal, diurnal and seasonal) variation of several environmental factors (salinity, temperature, dissolved oxygen, chlorophyll $a$, micro-seston dry weight, current velocity and plant biomass) in Areão.]

\section{Sampling and laboratory procedures}

Sampling was carried out monthly between May 1988 and April 1989 at low water of new-moon spring tides. Ten core samples $\left(10 \times 0.01 \mathrm{~m}^{2} ; 20 \mathrm{~cm}\right.$ depth) were taken randomly in a $500 \mathrm{~m}^{2}$ area bounded by the channel banks and including both subtidal and intertidal areas. The samples were sieved in the field through a $0.5 \mathrm{~mm}$ mesh and preserved in $10 \%$ formalin. Corophium multisetosum specimens were separated from the remaining macrobenthos and kept in $70 \%$ ethanol for further examination.

All collected individuals were counted, and undamaged specimens over a wide size range were selected for measurement of head length $\left(L_{h}\right.$, dorsal view, from tip of rostrum to posterior margin of head) and individual weight (w). Individual weights were recorded to the nearest $0.001 \mathrm{mg}$ by means of a CAHN electrobalance. The total biomass (ash-free dry weight, AFDW) of each replicate in the monthly samples was determined to the nearest $0.1 \mathrm{mg}$ by ignition of the dried specimens in a muffle-oven for $2 \mathrm{~h}$ at $450{ }^{\circ} \mathrm{C}$.

\section{Data analysis}

The non-parametric Kendall's rank correlation coefficient was used to determine the association of density and biomass of Corophium multisetosum with several environmental variables recorded monthly in the study area. This statistical analysis is appropriate for variables not normally distributed. Abundance data of C. multisetosum and other species present in the study area were normalised by a $\log (n+1)$-transformation to allow a Pearson product-moment correlation analysis. Details on environmental variables and species are given by Cunha and Moreira (1995).

The relationship between the ash-free dry weight (AFDW, mg) and head length $\left(L_{h}, \mathrm{~mm}\right)$ of Corophium multisetosum was established by the equation:

$\mathrm{AFDW}=a \times L_{h}^{b}$,

and its physiological condition was assessed using a condition index (CI) determined by the equation:

$\mathrm{CI}=\bar{w}_{i} / \bar{L}_{h}^{b}$,

where $\bar{w}_{i}=$ average individual weight $\left(\mathrm{mg}_{\mathrm{AFDW}}\right), \bar{L}_{h}=$ average head length $(\mathrm{mm})$, and $b=$ exponent of the allometric equation (1).

Annual production $(\mathrm{P})$ was estimated using the Hynes sizefrequency method modified by Menzies (1980):

$\mathbf{P}=\left[i \sum_{1}^{j}\left(\bar{d}_{j}-\bar{d}_{j+1}\right) \times \sqrt{\left(\bar{w}_{j} \times \bar{w}_{j+1}\right)}\right] \frac{12}{C P I}$,

where $i=$ number of size classes; $\bar{d}_{j}=$ mean density in size class $j$ (individuals $\mathrm{m}^{-2}$ ); $\bar{w}_{j}=$ mean individual weight in size class $j$ $\left(\mathrm{mg}_{\mathrm{AFDW}}\right)$; and $C P I=$ cohort production interval $(\mathrm{mo})$; and the multiple regression equation of Morin and Bourassa (1992):

$\log \mathrm{P}=-0.75+1.01 \log \bar{B}-0.34 \log \bar{M}+0.037 T^{\prime}$,

where $\bar{B}=$ mean annual biomass $\left(\mathrm{g}_{\mathrm{DW}} \mathrm{m}^{-2}\right) ; \bar{M}=$ mean individual weight $\left(\mathrm{g}_{\mathrm{DW}}\right)=\bar{B} \bar{D}^{-1} ; \bar{D}=$ mean annual density; $D W=$ dry 
weight; $\quad T^{\prime}=\sum B_{i} T_{i} / \sum B_{i} ; \quad B_{i}=$ biomass in sample $i ;$ and $T_{i}=$ water temperature in sample $i$.

With the first method, the mean individual ash-free dry weight in each size class $\left(\bar{w}_{j}\right)$ is obtained from an allometric equation, while with the second method the mean individual dry weight $(\bar{M})$ is obtained from the actually measured biomass for each monthly sample $\left(B_{i}\right)$.

\section{Results}

Temporal variation of density and biomass

Corophium multisetosum maintained extremely high densities all year round in the study area (Fig. 2). Water temperature and salinity fluctuations, depending mainly on the climatic conditions (e.g. insolation and rainfall), were the chief abiotic factors related to population fluctuations of $C$. multisetosum in Areão. A small peak of density and biomass occurred at the end of spring $\left(D=52.3 \times 10^{3} \quad\right.$ individuals $\mathrm{m}^{-2}$ in June, $B=16.7 \mathrm{~g} \mathrm{~m}^{-2}$ in July). A more effective period of increasing abundance and biomass occurred during the autumn, when temperature decreased from 23 to $18^{\circ} \mathrm{C}$, and maxima were reached in winter $\left(D=199.6 \times 10^{3}\right.$ individuals $\mathrm{m}^{-2}$ in December, $B=62.0 \mathrm{~g} \mathrm{~m}^{-2}$ in February). A gradual decrease in abundance and biomass occurred at low water temperatures $\left(10\right.$ to $\left.12^{\circ} \mathrm{C}\right)$. Summer minima $\left(D=21.6 \times 10^{3}\right.$ individuals $\mathrm{m}^{-2}$ in August, $B=7.1 \mathrm{~g} \mathrm{~m}^{-2}$ in September) occurred at the highest temperatures $\left(\approx 24^{\circ} \mathrm{C}\right)$. Increasing trends in abundance and biomass were observed when salinity varied between 1 and 3 psu. Minima $\left(D=22.4 \times 10^{3}\right.$ individuals $\mathrm{m}^{-2}, B=5.4 \mathrm{~g} \mathrm{~m}^{-2}$ in May) occurred at very low salinities $(<0.5 \mathrm{psu})$, during rainy periods.

Figure 2 illustrates the fluctuations of the Corophium multisetosum population (abundance and biomass) and

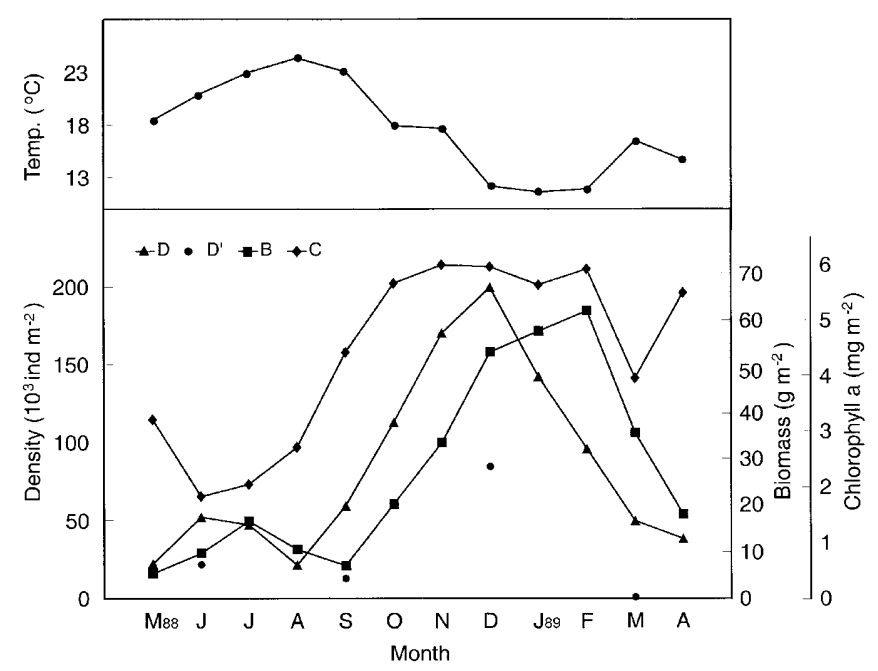

Fig. 2 Trends in density $(D)$ and biomass $(B)$ of Corophium multisetosum, chlorophyll $a$ concentration in sediment $(C)$ and water temperature over study period $\left[D^{\prime}\right.$ density of $C$. multisetosum estimated in previous study for same area (Queiroga 1990)] water temperature and chlorophyll concentration in the sediment, over the study period. The trends observed in chlorophyll concentration, density and biomass are similar, but occurred successively, with a 1 to 2 mo lag. During summer and autumn, an increasing concentration of chlorophyll was accompannied by increasing density and biomass of $C$. multisetosum. During winter, chlorophyll concentrations maintained maximal values $\left(\approx 6 \mathrm{mg} \mathrm{m}^{-2}\right)$ and, although the temperature was no longer favourable to reproduction (reflected by decreasing density), biomass continued to increase until February through individual growth.

Figure 3 shows the physiological condition $\left(\mathrm{CI}=\bar{w}_{i} / \bar{L}_{c}^{3.241}\right)$ of Corophium multisetosum over the study period (Fig. 3A) and its relation to chlorophyll concentration in the sediment (Fig. 3B). An increase in chlorophyll concentration from June to November was accompanied by an improvement in the physiological condition of the amphipod. Condition index (CI) was 1.5 in June; this increased gradually until it attained twice this value in December.

Both density and biomass were significantly correlated with chlorophyll in the sediment (positively) and with water temperature (negatively) (Table 1). Moreover, biomass was highly correlated with the concentration of chlorophyll observed 1,2 and 3 mo earlier ( $\tau$ : $0.639,0.689,0.611$, respectively; $P<0.005)$. This variable was also highly correlated with temperature $(\tau$ : -0.469 and -0.455 for the correlation of chlorophyll with temperature at high and low water, respectively; $P<0.025)$.

The temporal variation in density of Corophium multisetosum was positively correlated with salinity at low water and negatively correlated with plant biomass (mainly Potamogeton spp. and Myriophyllum spp.) and with oxygen saturation at low water (Table 1). The latter two factors were closely related to each other $(\tau: 0.489$; $P<0.025)$. Plant biomass displayed peak values in August and March and minimum values from November to February.

There was a significant positive correlation between biomass of Corophium multisetosum and both chlorophyll concentration and dissolved oxygen recorded at high water. The highest concentrations of chlorophyll in the water column were recorded from January to March (190 to $290 \mathrm{mg} \mathrm{m}^{-3}$ ), but a smaller peak occurred in September $\left(130 \mathrm{mg} \mathrm{m}^{-3}\right)$.

\section{Interaction with other species}

The abundance of Corophium multisetosum throughout the study period was significantly correlated with the abundance of only a few species. There was a positive correlation with the abundance of other crustaceans in the area (Gammarus chevreuxi, Leptocheirus pilosus, Cyathura carinata and Lekanesphaera hookeri) all of which showed quite similar trends in seasonal variation. Significant negative correlations were recorded between 


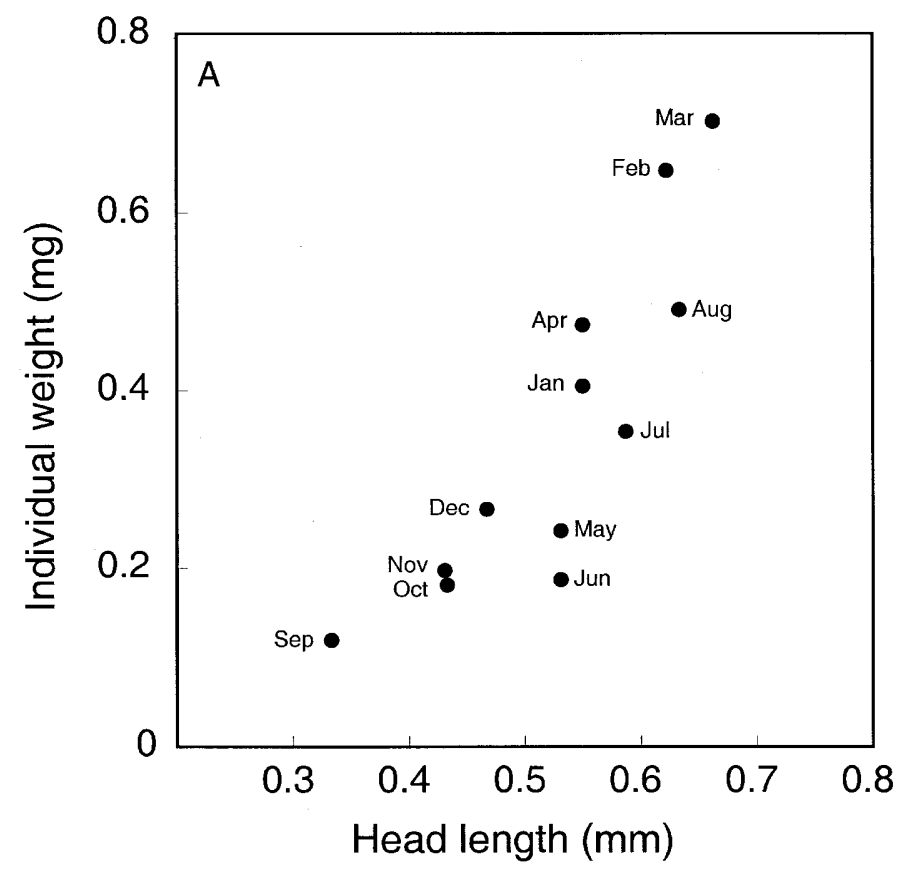

Fig. 3 A Corophium multisetosum. Changes in individual weight and head length over study period (May 1988 to April 1989); B relationship between physiological condition of $C$. multisetosum and chlorophyll $a$ concentration in sediment

Corophium multisetosum and the polychaete Nereis diversicolor, the oligochaete Ophidonais serpentina, and the gastropods Valvata piscinalis and Physa acuta, all of which occurred at relatively low densities (50 to 260 individuals $\mathrm{m}^{-2}$ ). However, the correlation of C. multisetosum abundance with that of the most abundant species, such as the gastropod Potamopyrgus jenkinsi $\left(103 \times 10^{3}\right.$ individuals $\mathrm{m}^{-2}$ ), and the oligochaete Limnodrilus hoffmeisteri $\left(8 \times 10^{3}\right.$ individuals $\left.\mathrm{m}^{-2}\right)$, was not significant.

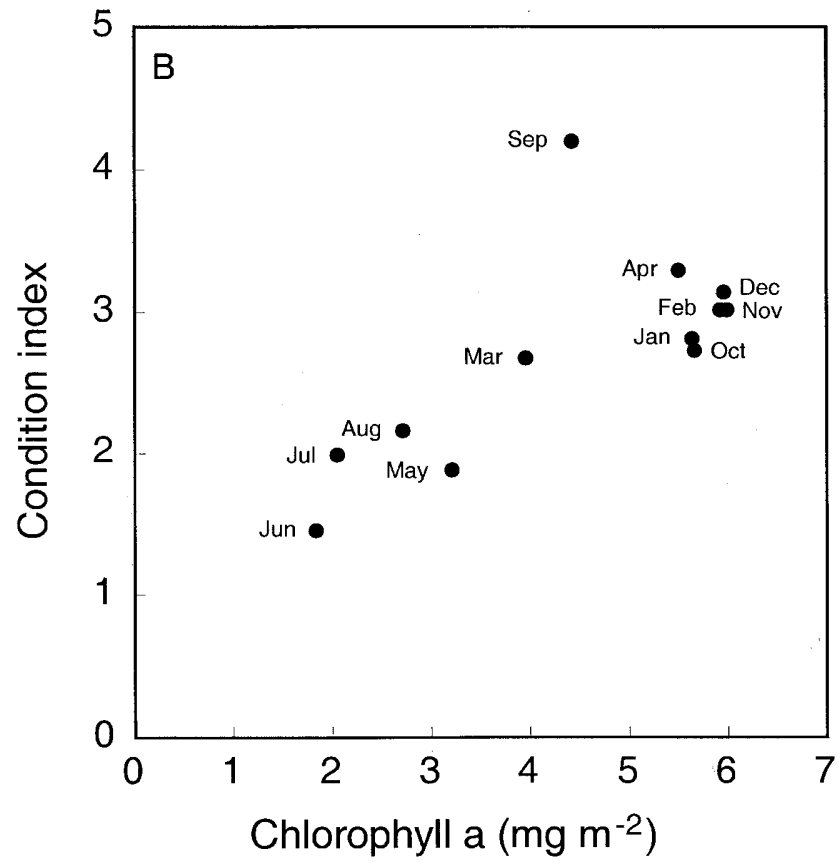

Production

The Hynes and Morin-Bourassa methods were used to estimate the secondary production of Corophium multisetosum since it was not possible to accurately discriminate the different overlapping cohorts (Cunha et al. 2000b).

For the determination of the mean annual cohort (Hynes method) individuals were divided into 12 sizeclasses (see also Cunha et al. 2000b, for demographic structure of the population). The mean individual weight of each size-class was obtained from the equation expressing the relationship (Fig. 4) between the ash-free dry weight (AFDW, mg) and head length $\left(L_{h}\right.$, in $\left.\mathrm{mm}\right)$ :
Table 1 Kendall's rank correlation $(\tau)$ between density (individuals $\mathrm{m}^{-2}$ ) and biomass, as ash-free dry wt $\left(\mathrm{g}_{\text {AFDW }} \mathrm{m}^{-2}\right)$ of Corophium multisetosum and several environmental factors recorded throughout $1 \mathrm{yr}$ period ( $H W$ high water; $L W$ low water; $D W$ dry wt; $* P<0.05$; $* * P<0.025 ; * * * P<0.005$ $(n=12$, one-tailed test $))$

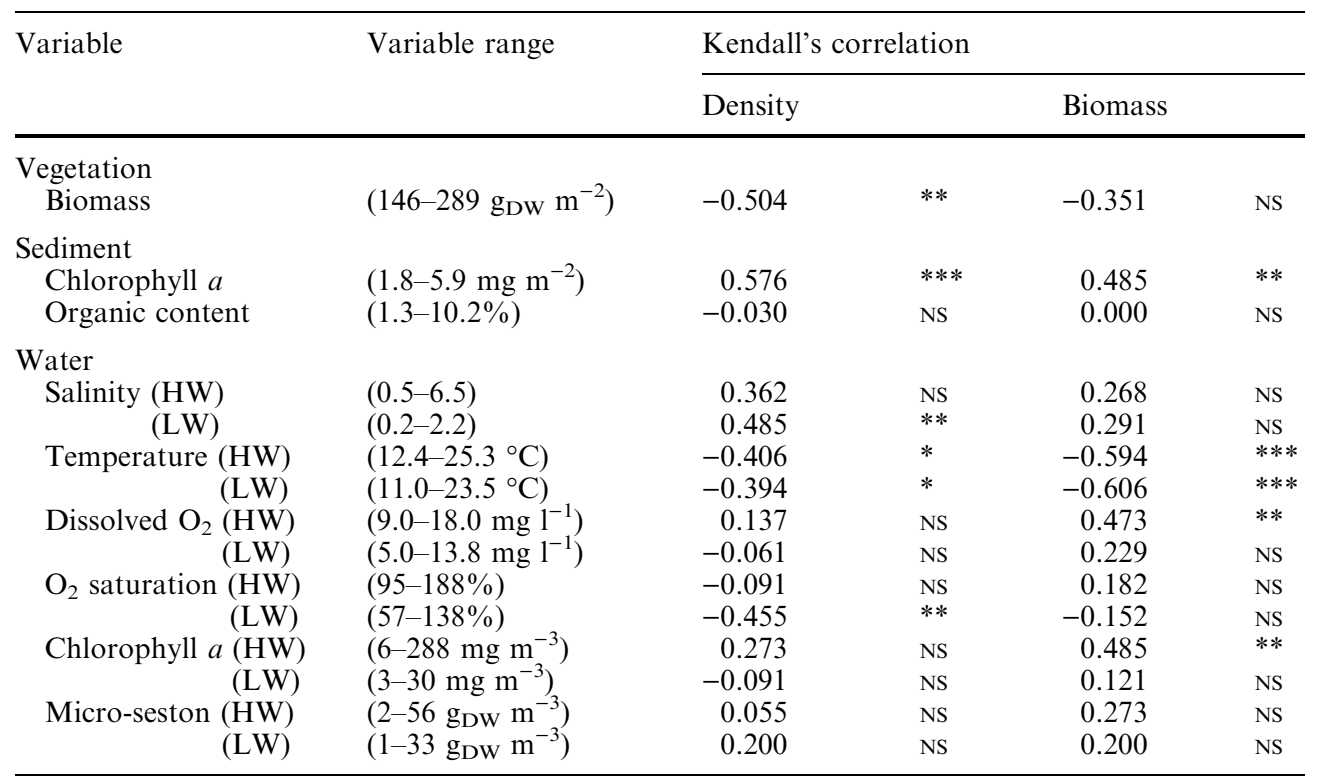


Fig. 4 Corophium multisetosum. Relationship between ash-free dry weight $(A F D W)$ and head length $\left(J\right.$ juveniles; $F_{n s}$ nonsetose females; $F_{\text {inc }}$ incubating females; $F_{e}$ empty females; $M$ males)

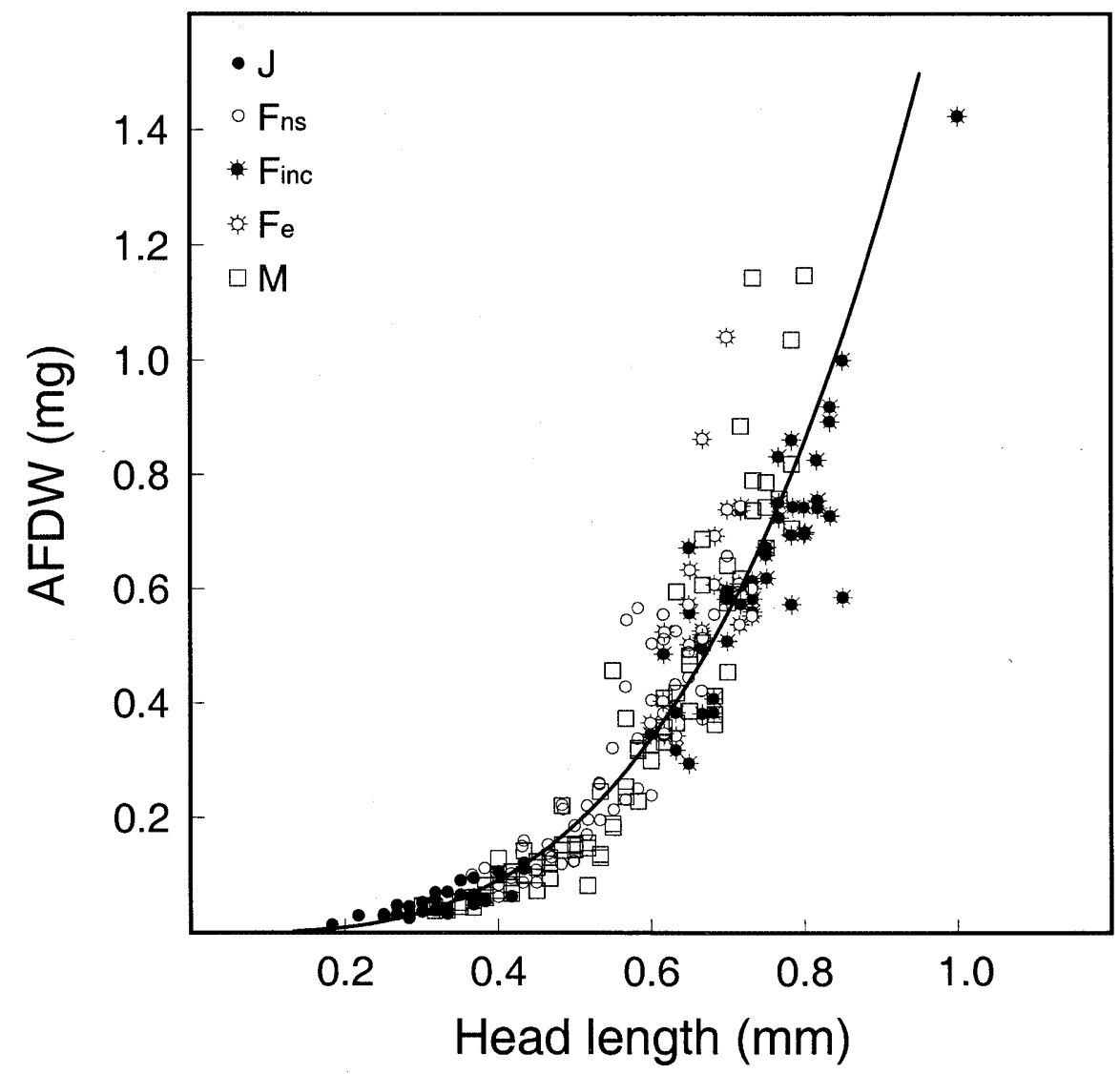

$$
\begin{aligned}
& \mathrm{AFDW}=1.7671 \times L_{h}^{3.241} \\
& (n=234 ; r=0.965, P>0.001 ; \\
& \left.\quad 0.183 \leq L_{h} \leq 1.000\right)
\end{aligned}
$$

where the exponent was significantly higher than 3 $\left(t_{\mathrm{obs}}=4.47 ; 232 d f ; P<0.001\right)$. The ash-free dry weight can be converted to dry weight using the equation:

$\mathrm{DW}=1.129 \times \mathrm{AFDW}$,

where in the value 1.129 was obtained from the data on mean percentage of ashes for Corophium multisetosum.

A correction factor (CPI) of $6 \mathrm{mo}$, corresponding to the mean longevity of Corophium multisetosum in Areão (Cunha et al. 2000b) was used. The estimate of pro- duction using the Hynes method, 250.95 gAFDw $\mathrm{m}^{-2} \mathrm{yr}^{-1}$ (Table 2), was lower than that obtained by the Morin-Bourassa method, $308.35 \mathrm{~g}_{\mathrm{DW} \mathrm{m}} \mathrm{yr}^{-1}$ $\left(\approx 273.02 \mathrm{~g}_{\text {AFDW }} \mathrm{m}^{-2} \mathrm{yr}^{-1}\right)$. The annual $\mathrm{P}: \overline{\mathrm{B}}$ ratio of C. multisetosum in the study area was high, and similar estimates (Table 2) were obtained by the two methods (10.14 and 9.92 for Hynes and Morin-Bourassa methods, respectively).

Seasonal estimates showed that the differences between the two methods were more important for the autumn/winter season. During this period, the mean density, mean biomass, production and $\mathrm{P}: \overline{\mathrm{B}}$ ratio were higher than in the spring/summer period (Table 2). The autumn/winter population contributed $\simeq 70 \%$ of the annual production of Corophium multisetosum in Areão.
Table 2 Corophium multisetosum. Production calculated by two different methods. Values are given per year and per season $(S p / S u$ spring/summer; $A u / W i$ autumn/winter) $[A F D W$ ash-free dry wt; $D W$ dry wt; $\bar{D}$ Mean density (individuals $\mathrm{m}^{-2}$ ); $\bar{B}$ mean biomass $\left(\mathrm{g} \mathrm{m}^{-2}\right) ; \bar{M}$ mean individual weight $(\mathrm{g}) ; P$ production $\left(\mathrm{g} \mathrm{m}^{-2}\right.$ per 6 mo or

\begin{tabular}{|c|c|c|c|c|c|c|c|}
\hline \multirow{2}{*}{$\begin{array}{l}\text { Method, } \\
\text { Period }\end{array}$} & \multirow[t]{2}{*}{$\bar{D}$} & \multirow[t]{2}{*}{$\bar{B}$} & \multirow[t]{2}{*}{$\bar{M}$} & \multicolumn{2}{|c|}{ Over 6 mo: } & \multicolumn{2}{|c|}{ Over 1 yr: } \\
\hline & & & & $\mathrm{P}$ & $\mathrm{P}: \overline{\mathrm{B}}$ & $\mathrm{P}$ & $\mathrm{P}: \overline{\mathrm{B}}$ \\
\hline \multicolumn{8}{|c|}{ Hynes (12 size-classes, AFDW) } \\
\hline $\mathrm{Sp}-\mathrm{Su}$ & 38788 & 16.21 & & 76.25 & 4.70 & & \\
\hline $\mathrm{Au}-\mathrm{Wi}$ & 130022 & 33.30 & & 174.69 & 5.25 & & \\
\hline Annual & 84405 & 24.76 & & & & 250.95 & 10.14 \\
\hline \multicolumn{8}{|c|}{ Morin-Bourassa $\left(T^{\prime}=15.16, \mathrm{DW}\right)$} \\
\hline $\mathrm{Sp}-\mathrm{Su}$ & 38788 & 18.55 & $415 \times 10^{-6}$ & 83.16 & 4.48 & & \\
\hline $\mathrm{Au}-\mathrm{Wi}$ & 130022 & 43.60 & $335 \times 10^{-6}$ & 222.45 & 5.10 & & \\
\hline Annual & 84405 & 31.07 & $368 \times 10^{-6}$ & & & 308.35 & 9.92 \\
\hline
\end{tabular}
per yr); $T^{\prime}$ temperature (weighted mean, $\left.{ }^{\circ} \mathrm{C}\right)$ ] 


\section{Discussion}

\section{Environmental factors}

Previous experiments on salinity and substrate selection (Queiroga 1990; Chatwin 1991) showed that Corophium multisetosum prefers salinities from 2.5 to $10 \mathrm{psu}$ and avoids the finest $(63 \mu \mathrm{m})$ and coarsest $(2 \mathrm{~mm})$ grades over a range of substrate particle-sizes. These results correspond to the observed field data for Areão, and may explain the remarkable density of $C$. multisetosum in the area. Further observations on the local distribution of $C$. multisetosum in neighbouring areas $( \pm 1 \mathrm{~km})$ also showed that density decreased both upstream and seawards. C. multisetosum appeared to avoid low-flow areas and substrates with a high percentage of fine particles, and it was usually absent from sediments with a black reduced layer. Laboratory experiments (Ré 1996) showed that in sediments consisting of $\approx 50 \%$ of fine particles $(<0.065 \mathrm{~mm})$, reproduction of $C$. multisetosum was inhibited and construction of tubes became difficult. In the presence of higher percentages of fine particles, the amphipod just burrows in the sediment.

The available literature on factors affecting the distribution and abundance of Corophium species is vast, although most studies focus on $C$. volutator and $C$. arenarium. These species are highly tolerant to salinity variations, and thus the nature of the substratum often determins their distribution (Gee 1961; Meadows $1964 a, b, c)$. However, McLusky (1968) suggested that the abundance and distribution of $C$. volutator in the Ythan estuary, Scotland, were controlled by a critical minimum salinity. The positive correlation observed between $C$. multisetosum abundance and salinity at low water in Areão is in accordance with the results of salinity-preference experiments which showed that very low salinities $(\approx 0.0 \mathrm{psu}$ ) were rejected (Queiroga 1990). Further laboratory experiments (Ré 1996) showed that at very low salinities $\left(<0.3 \mathrm{psu} ; T \approx 22^{\circ} \mathrm{C}\right)$ survivorship is significantly reduced, while intermediate values $(>2$ to $<18 \mathrm{psu}$ ) favour survivorship, growth and reproduction. Previous field data on C. multisetosum (Queiroga 1990) demonstrated that extremely low salinities were associated with severe decreases in abundance. In March 1986, when salinity remained close to $0.0 \mathrm{psu}$ at both low and high water, the estimated density of $C$. multisetosum in Areão was 827 individuals $\mathrm{m}^{-2}$, > 100 times less than in December 85 ( $D^{\prime}$ in Fig. 2). Since tides have little influence in Areão, rainfall is the main factor affecting salinity. Drastic decreases in C. multisetosum abundance may be associated with increased freshwater inflow following rainy periods on the stream catchment area. Year-to-year density fluctuations may occur, depending on rainfall. Casabianca (1972/1973) reported a mortality rate of $\sim 95 \%$ in $C$. insidiosum from Biguglia, Corsica, caused by decreased salinity and increased current velocity following exceptional rainfall.
The negative correlation between temperature and both abundance and biomass of Corophium multisetosum may seem unexpected. However, it must be considered that this is a cold-temperate species (Lincoln 1979), with its southern limit in Portugal. In principle, the minimum water temperature occurring in Areão $\left(8{ }^{\circ} \mathrm{C}\right)$ should not be limiting to a species that must endure much lower values in northern areas. However, long periods of high temperatures $\left(>24^{\circ} \mathrm{C}\right)$ may deter reproduction (Cunha et al. 2000a, b) and contribute to the summer minima of abundance and biomass. The possible physiological sensitivity of $C$. multisetosum to low oxygen concentrations may also explain the summer decline, which could be caused by either mortality or migration. Cunha and Moreira (1995) showed that, in summer, when dense vegetation and high temperatures occur, the oxygen concentrations, which reached oversaturation during the day in Areão, are followed by a drastic drop during the night $\left(\approx 2 \mathrm{mg} \mathrm{l}^{-1} ; 15\right.$ to $30 \%$ saturation). Physiological sensitivity of Corophium species to some factors such waste discharges, sulphide, and hypoxia has been mentioned or demonstrated by several authors (Segestråle 1959; Meadows et al. 1981; Esselink et al. 1989; Gamenick et al. 1996). However, other studies failed to establish any correlation between local distribution and abiotic factors (Murdoch et al. 1986; Ólaffson and Persson 1986; Jensen and Kristensen 1990; Hughes and Gerdol 1997).

The tube-building and feeding activities of Corophium spp. may interact with environmental factors and processes, for instance, enhancing substrate instability, reducing the density of micro-organisms and organic content (Meadows and Tait 1989; Gerdol and Hughes 1993, 1994a, b), or stimulating sediment-oxygen respiration and denitrification (Rysgaard et al. 1995). Such interactions prevent the interpretation of causal relations to the abundance of Corophium spp.. This could be the case of the observed negative correlation between the temporal variation of plant biomass and $C$. multisetosum abundance in Areão. In fact, high densities of $C$. multisetosum certainly contribute to sediment instability, disfavouring colonisation by rooted plants. However, plant roots may prevent burrowing. Murdoch et al. (1986) determined that plant detritus supplied $<5 \%$ of the nutritional demands of Corophium spp.. However, decay of vegetation during late summer and autumn is followed by an increase in bacterial decomposition activity and, consequently, an increase in food supply for detritus-feeders. This process probably favours the growing population of $C$. multisetosum during the autumn. Substrate instability, food supply and the above mentioned relationship to oxygen concentration illustrate the complexity of the interaction between $C$. multisetosum and rooted vegetation.

Corophium spp. are predominantly unselective deposit-feeders, although suspension-feeding and epipsammic browsing may also occur (Fenchel et al. 1975; Nielsen and Kofoed 1982). Several authors have shown that benthic microalgae, mainly diatoms, form a signif- 
icant part of their diet (Morrisey 1988a, b; Gerdol and Hughes 1994a, b; Smith et al. 1996). The importance of benthic microalgae to the nutritional requirements of C. multisetosum is suggested by the strong correlation between the density, biomass and physiological condition of the amphipod and the chlorophyll $a$ concentration in the sediments.

The negative correlation between chlorophyll $a$ concentration and temperature naturally contributes to the equally negative correlation between density and biomass of Corophium multisetosum and temperature.

\section{Interspecific relations}

In addition to the effect of environmental factors, interspecific relations, including competition, predation and amensalism, may also influence distribution and abundance of Corophium spp. Beukema and Flach (1995) suggested that the clear zonation of Corophium species in the Wadden Sea shores is determined by their physiological ability to endure prolonged emersion at the upper intertidal and by the outcome of their interaction with other species at the lower intertidal. Intensive sediment-reworking by Arenicola marina or high densities of Cerastoderma edule can be effective in reducing numbers of Corophium species, dissuading the amphipod from burrowing (Flach 1992, 1993; Flach and de Bruin 1993). However, data on possible negative interactions with other species such as Macoma balthica, Nereis diversicolor or Hydrobia ulvae are inconclusive or contradictory (Jensen 1988; Morrisey 1988a, b; Flach 1992; Jensen and Andre 1993; Hughes and Gerdol 1997). The results from Areão showed that the remarkably high density of Limnodrilus hoffmeisteri and Potamopyrgus jenkinsi had no significant effect on the seasonal variation of $C$. multisetosum. Moreover, the negative correlation with some low-density freshwater species cannot be ascribed to significant competitive interference, and is probably due to opposing effects of salinity fluctuations. Positive associations with other crustacean species are probably induced by coincident fluctuations resulting from similar life-history strategies.

It has been demonstrated that size-selective predation may influence the life-history patterns and population fluctuations of Corophium species (Wilson 1989; Matthews et al. 1992). These amphipods may complise a significant food resource for waders (Goss-Custard 1977; Peer et al. 1986; Jensen and Kristensen 1990), fishes, and decapods (Segestråle 1959; Wilson 1989). Although Corophium spp. are a substantial prey for fishes, Schneider and Harrington (1981) concluded that the number of fish predators would have to be one order of magnitude greater than the number of birds (sandpipers) to have the same impact on the prey population.

Ria de Aveiro is an important staging area for birds; waders begin to increase their density in October, reach a maximum in December, and remain until February or March. Despite the high density of invertebrates, Areão is not usually frequented by waders, except for the dunlin Calidris alpina, which visits the area occasionally during late spring. The absence of large intertidal flats, the existence of trees along the margins, and the distance $(\approx 20 \mathrm{~km})$ to the usual roosting sites probably render the area unattractive to these birds (Luís 1998, and personal communication).

The fish community in Areão includes mainly estuarine residents (Atherina boyeri, Platichthys flesus, Gobiidae, Syngnathidae), marine seasonal users (Dicentrarchus labrax, Chelon labrosus, Liza spp., Mugil cephalus) and the catadromous migrant Anguilla anguilla. All these species feed on invertebrates, either strictly or in combination with other types of food (plankton, plants, detritus, other fishes). A. anguilla is probably the main predator of Corophium multisetosum in the study area because it represents 10 to $12 \%$ of the abundance and 31 to $50 \%$ of the total biomass of the fish community (Rebelo 1992).

\section{Production}

Production and $\mathrm{P}: \overline{\mathrm{B}}$ estimates of Corophium species from European populations are summarised in Table 3 (different methods were used in the different areas). The highest production of $C$. insidiosum $\left(61 \mathrm{~g}_{\mathrm{Dw}} \mathrm{m}^{-2} \mathrm{yr}^{-1}\right)$ and $C$. volutator $\left(95.6 \mathrm{~g}_{\mathrm{DW} \mathrm{m}} \mathrm{m}^{-2} \mathrm{yr}^{-1}\right)$, observed in the Biguglia lagoon, Corsica (Casabianca 1975) and in the Thames estuary, England (see Möller and Rosenberg 1982), respectively, was much lower than the production of C. multisetosum in Areão $\left(308 \mathrm{~g}_{\mathrm{DW}} \mathrm{m}^{-2} \mathrm{yr}^{-1}\right)$. The lowest production $\left(0.012 \mathrm{~g}_{\mathrm{AFDW}} \mathrm{m}^{-2} \mathrm{yr}^{-1}\right)$ was estimated for C. sextoni in Torbay, England (Hughes 1978). The latter is a fouling species, and its production values are dependent upon the availability of suitable hard substrata.

The $\mathrm{P}: \overline{\mathrm{B}}$ estimates for Corophium species show a wide variation but, in general, are higher than for other amphipod species (Birklund 1977; Collie 1985). Variation of the $\mathrm{P}: \overline{\mathrm{B}}$ ratio may occur in relation to water temperature and size (Schwinghamer et al. 1986; Morin and Bourassa 1992). Gratto et al. (1983) ascribed the difference in the production and $\mathrm{P}: \overline{\mathrm{B}}$ ratios of two populations of C. volutator from the Bay of Fundy to distinct life-history patterns induced by different temperatures. The maximal $\mathrm{P}: \overline{\mathrm{B}}$ ratio of 19.5 , recorded for $C$. insidiosum in the Biguglia lagoon (Casabianca 1975), may be explained both by the high water temperatures $\left(30\right.$ to $\left.34{ }^{\circ} \mathrm{C}\right)$ and the small size of the species (length up to $\sim 5 \mathrm{~mm}$ ) relative to C. volutator $(10 \mathrm{~mm})$ and C. multisetosum $(10 \mathrm{~mm})$. The $\mathrm{P}: \overline{\mathrm{B}}$ ratio of $C$. multisetosum (9.9 to 10.1) compared well with the highest values estimated for $C$. volutator in the Gullmarsvik (11.3) and in the Sandvik (10.4), in Sweden, using a cohort separation method (Möller and Rosenberg 1982). During the winter, these areas were ice-covered for several months. The major contribution to the production, up to $85 \%$, was made in the summer period (June/August) when the temperature rose to $\sim 20^{\circ} \mathrm{C}$. In 
Table 3 Corophium spp. Production estimates $\left(\mathrm{g} \mathrm{m}^{-2} \mathrm{yr}^{-1}\right)$. *Values from Denmark estimated over 4 mo period (May to September) $D W$ dry wt; $A F D W$ ash-free dry wt

\begin{tabular}{|c|c|c|c|}
\hline $\begin{array}{l}\text { Species, } \\
\text { Location }\end{array}$ & Production & $\mathrm{P}: \overline{\mathrm{B}}$ & Source \\
\hline \multicolumn{4}{|l|}{ C. insidiosum } \\
\hline Denmark & $0.23-8.37 *(\mathrm{DW})$ & $1.8-4.9$ & Birklund (1977) \\
\hline Corsica & 3-61 (DW) & $12.0-19.5$ & Casabianca (1975) \\
\hline \multicolumn{4}{|l|}{ C. curvispinum } \\
\hline The Netherlands & 5.85-11.26 (AFDW) & $2.7-3.5$ & Rajagopal et al. (1999) \\
\hline \multicolumn{4}{|l|}{ C. sextoni } \\
\hline England & $0.012-0.016$ (AFDW) & $2.1-2.8$ & Hughes (1978) \\
\hline \multicolumn{4}{|l|}{ C. volutator } \\
\hline Sweden & 1.14-26.71 (AFDW) & $5.1-11.3$ & Möller and Rosenberg (1982) \\
\hline Denmark & $2.46-3.80 *(\mathrm{DW})$ & $3.2-4.4$ & Birklund (1977) \\
\hline England & $95.6(\mathrm{DW})$ & 7.7 & Mossman $(1977)^{\mathrm{a}}$ \\
\hline Canada & $8.8-22.1$ (DW) & $2.9-6.8$ & Gratto et al. (1983) \\
\hline \multicolumn{4}{|l|}{ C. multisetosum } \\
\hline Portugal & 250.95 (AFDW) & 10.1 & This study \\
\hline Portugal & 308.35 (DW) & 9.9 & This study \\
\hline
\end{tabular}

${ }^{a}$ Unpublished thesis cited by Möller and Rosenberg (1982)
Areão, the most productive period of $C$. multisetosum occurred during the autumn at temperatures around 15 to $18{ }^{\circ} \mathrm{C}$. These data suggest that the weighted temperature $\left(T^{\prime}\right)$ is probably a better indicator than average annual temperature when comparing $\mathrm{P}: \overline{\mathrm{B}}$ estimates from different populations because it accounts for the specific pattern of biomass fluctuations throughout the year.

Morin and Bourassa (1992) found that production is directly proportional to the mean annual biomass, while the $\mathrm{P}: \overline{\mathrm{B}}$ ratio is independent of biomass (see also Banse and Mosher 1980; Brey 1990). Our data confirm this: despite the differences in the estimates of $\bar{B}$ and $\mathrm{P}$ obtained by the two methods, the values of the $\mathrm{P}: \overline{\mathrm{B}}$ ratio coincided. The difference between the two production estimates $(8 \%)$ may be explained by differences in biomass assessment: the Hynes method determines biomass by an allometric equation, while the Morin-Bourassa method uses the actual measured biomass. The mean biomass estimated by the Hynes method was 24.76, 16.21 and $33.30 \mathrm{~g}_{\text {AFDW }} \mathrm{m}^{-2}$ for the $1 \mathrm{yr}$ period, the spring/summer, and the autumn/winter seasons, respectively. The corresponding values obtained from direct determination of biomass were 27.51, 16.08 and 38.95 , showing that the allometric regression underestimated the actual measured mean annual biomass by $\sim 10 \%$ and the autumn/winter mean biomass by $\sim 14.5 \%$. These results indicate that the use of a single annual allometric relation is not appropriate to accurately estimating seasonal production. Because of the difference in the physiological conditions of the population during the two seasons (Fig. 3A), separate allometric relations should have been determined.

Autumn/winter was the most productive period, mainly as a result of the extremely high density and biomass of Corophium multisetosum at this time. The difference in seasonal $\mathrm{P}: \overline{\mathrm{B}}$ ratios reflects different demographic structures of the population during the two periods. Recruitment was higher in autumn than in spring (Cunha et al. 2000b), and the higher percentage of juveniles resulted in a smaller average size and contributed to the higher $\mathrm{P}: \overline{\mathrm{B}}$ ratio. The exponents that characterise the allometry of $\mathrm{P}: \overline{\mathrm{B}}$ with average size are negative (Schwinghamer et al. 1986; Morin and Bourassa 1992). The effect of the demographic structure in production and $\mathrm{P}: \overline{\mathrm{B}}$ estimates is accounted for by the use of a mean cohort in the Hynes method and by the mean individual weight $(\bar{M})$ in the Morin-Bourassa method.

\section{Final remarks}

The nature of the sediment and the favourable environmental conditions, especially during the autumn, as well as the high availability of food resources, enable Corophium multisetosum to establish a dense and highly productive population in Areão. This population is one of the most abundant ever reported for Corophium species. A similar value of $200 \times 10^{3}$ individuals $\mathrm{m}^{-2}$ was estimated for a C. multisetosum population in the Dead Vistula, Poland (Janta 1995), while the maximal density reported for $C$. volutator was $120 \times 10^{3}$ individuals $\mathrm{m}^{-2}$ in Bassholm, Sweden (Möller and Rosenberg 1982).

The sediment surface occupied by each individual of Corophium volutator orientalis was determined by Omori and Tanaka (1998), who estimated the maximum densities as $602,163,83$ and $50 \times 10^{3}$ individuals $\mathrm{m}^{-2}$ for juveniles, young, females and males, respectively. Considering that $C$. multisetosum and $C$. volutator are about the same size, the densities in Areão may be close or even above the theoretical maximal density, and the population is probably under high intraspecific competition pressure. Previous evidence from other Corophium species indicates that dense populations may experience intraspecific competition (Wilson 1989; Jensen and Kristensen 1990; Matthews et al. 1992). In such cases, swimming activity usually increases and high mortality rates or emigration of juveniles may occur (Jensen and Kristensen 1990). The implications of the swimming 
behaviour of $C$. volutator in dispersal and colonisation have been discussed by Hughes (1988) (see also Essink et al. 1989; Hughes and Horsfall 1990).

In a population open to migration, production is lost to, and gained from, other areas. Because of the extremely high densities of Corophium multisetosum in Areão, especially during the autumn, intraspecific competition inducing swimming activity and migration may occur, and an important part of the production is probably exported to other areas. Further research should address the hypothesis that $C$. multisetosum in Areão constitutes a stock population for the colonisation of other areas in Ria de Aveiro. Quantitative data on the pelagic occurrence and dispersal of $C$. multisetosum are needed to assess the importance of this population in energetic and genetic fluxes within the Ria.

\section{References}

Banse K, Mosher S (1980) Adult body mass and annual production biomass relationships in field populations. Ecol Monogr 50: 355-379

Barnard JL, Karaman GS (1991) The families and genera of marine gammaridean Amphipoda (except marine gammaroids). Rec Aust Mus (Suppl) 13: 1-866

Beukema JJ, Flach EC (1995) Factors controlling the upper and lower limits of the intertidal distribution of two Corophium species in the Wadden Sea. Mar Ecol Prog Ser 125: 117-126

Birklund J (1977) Biomass, growth and production of the amphipod Corophium insidiosum Crawford, and preliminary notes on Corophium volutator (Pallas). Ophelia 16: 187-203

Brey T (1990) Estimating productivity of macrobenthic invertebrates from biomass and mean individual weight. Meeresforsch Rep mar Res 32: 329-343

Casabianca M-L (1972/1973) Influence des apports d'eau douce sur la dynamique des populations de crustacés constructeurs de l'étang de Biguglia, Corse (Corophium insidiosum C; Tanais cavolinii ME, Erichthonius brasiliensis D). Vie Milieu 23C: $45-63$

Casabianca M-L (1975) Méthode de calcul de la production par estimation de la mortalité. Application à une population à structure complexe du crustacé Corophium insidiosum Crawford (Lagune de Biguglia, Corse). Cr hebd Séanc Acad Sci, Paris 280: $1139-1142$

Chatwin AC (1991) The effect of sediment particle size on habitat selection of Corophium multisetosum. MSc thesis. University of Southampton, Southampton, England

Collie JS (1985) Life history and production of three amphipod species on Georges Bank. Mar Ecol Prog Ser 22: 229-238

Corrochano A, Galera M, Bernardes CA, Barba P (1997) Características de la llanura intermareal asociada al canal de Mira (dominio interno del complejo isla-barrera de Aveiro, Portugal). Geogaceta 22: 47-50

Cunha MR, Moreira MH (1995) Macrobenthos of Potamogeton and Myriophyllum beds in the upper reaches of Canal de Mira (Ria de Aveiro, NW Portugal): community structure and environmental factors. Neth J aquat Ecol 29: 377-390

Cunha MR, Moreira MH, Sorbe JC (2000a) Predicting amphipods' brood size variation in brackish environments: an empirical model for Corophium multisetosum Stock, 1952 (Corophiidae) in Ria de Aveiro (NW Portugal). $\mathbf{J}$ exp mar Biol Ecol 248: 207-223

Cunha MR, Sorbe JC, Moreira MH (2000b) The amphipod Corophium multisetosum (Corophiidae) in Ria de Aveiro (NW Portugal). I. Life history and aspects of reproductive biology. Mar Biol 137: 637-650
Esselink P, Van Belkum J, Essink K (1989) The effect of organic pollution on local distribution of Nereis diversicolor and Corophium volutator. Neth J Sea Res 23: 232-332

Essink K, Kleef HL, Visser W (1989) On the pelagic occurrence and dispersal of the amphipod Corophium volutator. $\mathrm{J}$ mar biol Ass UK 69: 11-15

Fenchel T, Kofoed LH, Lappalainen A (1975) Particle size selection of two deposit feeders: the amphipod Corophium volutator and the prosobranch Hydrobia ulvae. Mar Biol 30: 119-128

Flach EC (1992) The influence of four macrozoobenthic species on the abundance of the amphipod Corophium volutator on tidal flats of the Wadden Sea. Neth J Sea Res 29: 379-394

Flach EC (1993) The distribution of the amphipod Corophium arenarium in the Dutch Wadden Sea: relationships with sediment composition and the presence of cockles and lugworms. Neth J Sea Res 31: 281-290

Flach EC, de Bruin W (1993) Effects of Arenicola marina and Cerastoderma edule on distribution, abundance and population structure of Corophium volutator in Gullmarsfjorden western Sweden. Sarsia 78: 105-118

Gamenick I, Jahn A, Vopel K, Giere O (1996) Hypoxia and sulphide as structuring factors in a macrozoobenthic community on the Baltic Sea shore: colonisation studies and tolerance experiments. Mar Ecol Prog Ser 144: 73-85

Gee JM (1961) Ecological studies in South Benfleet Creek with special reference to the amphipod genus Corophium. Essex Nat 30: 291-309

Gerdol V, Hughes RG (1993) Effect of the amphipod Corophium volutator on the colonisation of mud by the halophyte Salicornia europaea. Mar Ecol Prog Ser 97: 61-69

Gerdol V, Hughes RG (1994a) Feeding behaviour and diet of Corophium volutator in an estuary in southeastern England. Mar Ecol Prog Ser 114: 103-108

Gerdol V, Hughes RG (1994b) Effect of Corophium volutator on the abundance of benthic diatoms, bacteria and sediment stability in two estuaries in southeastern England. Mar Ecol Prog Ser 114: 109-115

Goss-Custard JD (1977) Predator responses and prey mortality in redshank Tringa totanus (L.) and a preferred prey Corophium volutator (Pallas). J Anim Ecol 46: 21-35

Gratto GW, Thomas MLH, Bleakney JS (1983) Growth and production of the intertidal amphipod Corophium volutator (Pallas) in the inner and outer Bay of Fundy. Proc Nova Scotia Inst Sci 33: 47-55

Hughes RG (1978) Production and survivorship of epizoites of the hydroid Nemertesia antennina (L.). J mar biol Ass UK 58: 333-345

Hughes RG (1988) Dispersal by benthic invertebrates: the in situ swimming behaviour of the amphipod Corophium volutator. J mar biol Ass UK 68: 565-579

Hughes RG, Gerdol V (1997) Factors affecting the distribution of Corophium volutator in two estuaries in south eastern England. Estuar cstl, Shelf Sci 44: 621-627

Hughes RG, Horsfall IM (1990) Differences in the swimming behaviour of the amphipod Corophium volutator from different populations. J mar biol Ass UK 70: 143-148

Janta A (1995) Distribution of Corophium multisetosum Stock, 1952 (Crustacea, Amphipoda) in European waters with some notes on its ecology. Polskie Archwm Hydrobiol 42: 395-399

Jensen KT (1988) Recruitment and survival of Nereis diversicolor O.F. Müller and Corophium volutator (Pallas) in an artificial saltwater lagoon in the Danish Wadden Sea. Kieler Meeresforsch 6: 366-373

Jensen KT, Andre C (1993) Field and laboratory experiments on interactions among an infaunal polychaete, Nereis diversicolor, and two amphipods, Corophium volutator and C. arenarium: effects on survival, recruitment and migration. J exp mar Biol Ecol 168: 259-278

Jensen KT, Kristensen LD (1990) A field experiment on competition between Corophium volutator (Pallas) and Corophium arenarium Crawford (Crustacea: Amphipoda) effects on survival, reproduction and recruitment. J exp mar Biol Ecol 137: 1-24 
Lincoln RG (1979) British marine amphipoda: Gammaridea. Trustees of the British Museum (Natural History), London

Luís AS (1998) Influência de factores humanos e naturais nas limícolas (Aves, Charadrii) invernantes na Ria de Aveiro, com especial referência ao Pilrito-comum (Calidris alpina L.). $\mathrm{PhD}$ thesis. Universidade de Aveiro, Aveiro, Portugal

Marques JC, Bellan-Santini D (1985) Contribution à l'étude systématique et écologique des amphipodes (Crustacea-Amphipoda) des côtes du Portugal. Premier inventaire des espèces (Gammariens et Caprelliens). Ciênc Biol (Ser Ecol Sist) 5: 299-353

Marques JC, Bellan-Santini D (1986) Crustacés amphipodes des côtes du Portugal: faune du Canal de Tavira, des Salines de Marim (Ria Formosa) et de la Lagune de Santo André. Anais Fac Ciênc Porto 6: 217-243

Marques JC, Bellan-Santini D (1990) Faune d'amphipodes des milieux lagunaires du Portugal: actualisation des données et comparison avec d'autres systémes Atlantiques et Méditerranéens. Mésogée 50: 53-61

Matthews SL, Boates JS, Walde SJ (1992) Shorebird predation may cause discrete generations in an amphipod prey. Ecography 15: 393-400

McLusky DS (1968) Some effects of salinity on the distribution and abundance of Corophium volutator in the Ythan estuary. J mar biol Ass UK 48: 443-454

Meadows PS (1964a) Experiments on substrate selection by Corophium species: films and bacteria on sand particles. J exp Biol 41: 499-511

Meadows PS (1964b) Experiments on substrate selection by Corophium species: depth selection and population density. J exp Biol 41: 677-687

Meadows PS (1964c) Substrate selection by Corophium species the particle size of substrates. J Anim Ecol 33: 487-394

Meadows PS, Deans EA, Anderson JG (1981) Responses of Corophium volutator to sediment sulphide. J mar biol Ass UK 61: 739-748

Meadows PS, Tait J (1989) Modification of sediment permeability and shear strength by two burrowing invertebrates. Mar Biol 101: $75-82$

Menzies CA (1980) A note on the Hynes method of estimating secondary production. Limnol Oceanogr 25: 770-773

Möller P, Rosenberg R (1982) Production and abundance of the amphipod Corophium volutator on the west coast of Sweden. Neth J Sea Res 16: 127-140

Moreira MH, Queiroga H, Machado MM, Cunha MR (1993) Environmental gradients in a southern Europe estuarine system: Ria de Aveiro, Portugal. Implications for soft bottom macrofauna colonisation. Neth $J$ aquat Ecol 27: 465-482

Morin A, Bourassa N (1992) Modèles empiriques de la production annuelle et $\mathrm{du}$ rapport $\mathrm{P} / \mathrm{B}$ d'invertébrés benthiques d'eau courante. Can J Fish aquat Sciences 49: 532-539

Morrisey DJ (1988a) Differences in effects of grazing by depositfeeders Hydrobia ulvae (Pennant) (Gastropoda: Prosobranchia) and Corophium arenarium Crawford (Amphipoda) on sediment microalgal populations. I. Qualitative differences. J exp mar Biol Ecol 118: 33-42

Morrisey DJ (1988b) Differences in effects of grazing by depositfeeders Hydrobia ulvae (Pennant) (Gastropoda: Prosobranchia) and Corophium arenarium Crawford (Amphipoda) on sediment microalgal populations. I. Quantitative differences. J exp mar Biol Ecol 118: 43-53
Mossman DE (1977) The energetics of Corophium voutator (Pallas). Unpublished thesis. University of London, London, UK

Murdoch MH, Bärlocher F, Laltoo ML (1986) Population dynamics and nutrition of Corophium volutator (Pallas) in the Cumberland Basin (Bay of Fundy) J exp mar Biol Ecol 103: 235-249

Nielsen MV, Kofoed LH (1982) Selective feeding and epipsammic browsing by the deposit-feeding amphipod Corophium volutator. Mar Ecol Prog Ser 10: 81-88

Ólafsson EB, Persson LE (1986) The interaction between Nereis diversicolor O.F. Müller and Corophium volutator Pallas as a structuring force in a shallow brackish sediment. J exp mar Biol Ecol 103: 103-117

Omori K, Tanaka M (1998) Estimation of maximum density of a mudflat amphipod, Corophium volutator orientalis (Amphipoda: Crustacea) on the basis of its occupied area. J exp mar Biol Ecol 231: $31-45$

Peer DL, Linkletter LE, Hicklin PW (1986) Life history and reproductive biology of Corophium volutator (Crustacea: Amphipoda) and the influence of shorebird predation on population structure in Chignecto Bay, Bay of Fundy, Canada. Neth J Sea Res 20: 359-373

Queiroga H (1990) Corophium multisetosum (Amphipoda: Corophiidae) in Canal de Mira, Portugal: some factors that affect its distribution. Mar Biol 104: 397-402

Rajagopal S, van der Velde G, Paffen BGP, Bij de Vaate A (1999) Growth and production of Corophium curvispinum G.O. Sars, 1895 (Amphipoda) an invader in the lower Rhine. In: Schram FR, von Vaupel Klein C (eds) Crustaceans and the biodiversity crisis. Vol.1. Brill, Leiden, pp 457-472

Ré A (1996) Estudo da utilização de Corophium multisetosum (Amphipoda: Corophiidae) na avaliação ecotoxicológica de sedimentos estuarinos e marinhos. MSc thesis. Universidade de Aveiro, Aveiro, Portugal

Rebelo JE (1992) The ichthyofauna and abiotic hydrological environment of the Ria de Aveiro, Portugal. Estuaries 15: 403-413

Rysgaard S, Christensen PB, Nielsen LP (1995) Seasonal variation in nitrification and denitrification in estuarine sediment colonised by benthic microalgae and bioturbating infauna. Mar Ecol Prog Ser 126: 111-121

Schneider DC, Harrington BA (1981) Timing of shorebird migration in relation to prey depletion. Auk 98: 801-811

Schwinghamer P, Hargrave B, Peer D, Hawkins CM (1986) Partitioning of production and respiration among size groups of organisms in an intertidal benthic community. Mar Ecol Prog Ser 31: 131-142

Segestråle SG (1959) Synopsis of data on the crustaceans Gammarus locusta, Pontoporeia affinis and Corophium volutator (Amphipoda Gammaridea). Commentat biol 20: 1-23

Smith D, Hughes RG, Cox EJ (1996) Predation of epipelic diatoms by the amphipod Corophium volutator and the polychaete $\mathrm{Ne}$ reis diversicolor. Mar Ecol Prog Ser 145: 53-61

Stock JH (1952) Some notes on the taxonomy, the distribution and the ecology of four species of the amphipod genus Corophium (Crustacea, Malacostraca). Beaufortia 21: 1-10

Teles M, Negro M, Rodrigues D (1990) Elaboração de um sistema de modelos matemáticos para apoio da sua gestão integrada. In: IV Encontro Nacional de Saneamento Básico; Ria de Aveiro: que futuro? GRIA/UA, Aveiro, pp 99-112

Wilson WH Jr (1989) Predation and the mediation of intraspecific competition in an infaunal community of the Bay of Fundy. J exp mar Biol Ecol 132: 221-245 